\begin{tabular}{l|l} 
Notaice & e-ISSN: $2655-9404$ \\
2 No. 1, Februari 2019 & DOI: $10.20473 /$ ntr.v2i1.13100
\end{tabular}

Article history: Submitted 15 December 2018 ; Accepted 8 January 2019; Available online 1 February 2019.

\title{
Prosperity of the Process and Issuance of Regional Bonds and Risk of Public Bonds Registration in Indonesia
}

\author{
Sarah Wina Annisa, Mega Rahmawati Combo and Azizah Afaf \\ megarahma2701@gmail.com \\ Universitas Airlangga
}

\begin{abstract}
Making transactions can get a lot of profit, then there are several ways, one of which is in the form of investing. To make investments can be done by individuals or a person entity that has excess funds or is often called a company securities. Regulations regarding in Municipal Bonds are not the same as arrangements in corporate bonds and corporate bonds themselves, basically payment of Municipal Bonds made by this Regional Government comes from funds from the utilization / use of infrastructure built from publishing the regional bonds and reserve funds in the APBD must be allocated to repayment. it is important to research how to regulate and the process of issuing regional bonds. From this background can be drawn formulation of the problem, namely, What is the validity of the regulation and issuance process of Municipal Bonds and the risk of issuing Municipal Bonds in Indonesia? The results of the formulation of the problem that the author took was that all the rules related to procedures and issuance of municipal bonds is clear and regulated in law -invite, namely Law Number 33 of 2004 concerning Financial Balance between the Central Government and Regional Government, Government Regulation Number 30 In 2011 concerning Regional Loans, Minister of Finance Regulation Number 180 / PMK.07 / 2015 concerning Amendments to Regulation of the Minister of Finance Number 111 / PMK.07 / 2012 concerning Procedures for Issuance and Accountability of Bonds Area. Issuance of bonds can also be done through a public offering.
\end{abstract}

Keywords: Bonds; Issuance of Municipal Bonds; Regional Government.

\begin{abstract}
Abstrak
Melakukan transaksi dapat memperoleh keutungan yang sangat banyak, maka ada beberapa cara yakni salah satunya dengan bentuk melakukan penanaman modal. Untuk melakukan penanaman modal dapat dilakukan oleh individu atau suatu entitas yang mempunyai kelebihan dana atau yang sering disebut perusahaan sekuritas. Pengaturan mengenai risiko dalam Obligasi Daerah tidak sama dengan pengaturan dalam obligasi perusahaan, pada dasarnya pembayaran Obligasi Daerah yang dilakukan oleh Pemerintah Daerah ini berasal dari dana hasil pemanfaatan/penggunaan infrastruktur yang di bangun dari penerbitan obligasi daerah tersebut dan dana cadangan dalam APBD yang harus dialokasikan untuk pelunasan pembayaran. penting adanya untuk meneliti mengenai bagaimana pengaturan dan proses penerbitan obligasi daerah. Dari dari latar belakang tersebut dapat ditarik rumusan masalah yaitu, Bagaimana Analisa pengaturan dan proses penerbitan Obligasi Daerah di Indonesia?. Hasil dari rumusan masalah yang penulis ambil adalah Bahwa segala aturan terkait prosedur dan penerbitan obligasi daerah sudah jelas dan diatur dalam undang-undang, yaitu Undang-Undang Nomor 33 Tahun 2004 Tentang Perimbangan Keuangan antara Pemerintah Pusat dan Pemerintahan Daerah, Peraturan Pemerintah Nomor 30 Tahun 2011 Tentang Pinjaman Daerah, Peraturan Menteri Keuangan Nomor 180/PMK.07/2015 Tentang Perubahan Atas Peraturan Menteri Keuangan Nomor 111/PMK.07/2012 Tentang Tata Cara Penerbitan dan Pertanggungjawaban Obligasi Daerah. Penerbitan Obligasi Juga dapat dilakukan melalui penawaran umum.

Kata Kunci: Obligasi; Penerbitan Obligasi Daerah; Pemerintah Daerah.
\end{abstract}




\section{Introduction}

In implementing regional autonomy, the Regional Government has the rights and obligations to regulate and manage its government affairs, but encounters limitations in funding sources. Most districts and cities rely heavily on balancing funds provided by the Central Government. Regional Income Sources in the form of taxes, levies, proceeds of regionally owned companies, the results of management of other regional assets that are separated, and other legitimate local revenue originating from limited Regional Original Income. This is because the sources of funding are absorbed in routine spending. With these financial conditions, it is certainly difficult for local governments to implement various development projects due to budget constraints. Therefore various breakthroughs must be carried out by the regional government in an effort to find development funding sources in order to achieve the successful implementation of regional autonomy.

In making transactions that get a lot of profit then there are several ways, namely with the form of investment. To do these investments can be made by individuals or an entity have excess funds or are often called securities companies. In the world of commerce, various types of letters are known and in general people say these letters as Securities. Securities based on the fact that the letter has value for money or can be exchanged with a sum of money or what is mentioned in the letter can be assessed or exchanged with money, the letters are notes, acceptances, checks, shares, bonds, mortgages, ceel, tickets trains, safekeeping letters, etc. ${ }^{1}$

The definition of such securities mentioned above is actually not appropriate. What is meant by securities in the sense of commercial law is not thus. So that it can be said as a Securities in the sense of the law trade, it is necessary to fulfill certain conditions which are the characteristics of the letter as securities. In the Commercial Code (KUHD) no there are definitions of securities. Therefore, it can only be concluded from the characteristics the characteristics or conditions stipulated in the

${ }^{1}$ Abdul kadir Muhammad, Hukum Dagang Tentang Surat-Surat Berharga (Citra Aditya Bakti 1998).[4]. 
articles in the KUHD, which are included in a letter that can be said as a securities. ${ }^{2}$ The purpose of investing is get capital gains and dividends. That is, capital gains are profits obtained by investors from the sale and purchase of shares, in the form of a difference between the sale value higher than the lower buy value. ${ }^{3}$ In addition to selling shares to public, there are several alternatives regarding funding that can be done within capital markets, namely bonds or sukuk, medium term notes (MTN) or mutual funds Limited Participation (RDPT).

Definition of Bonds Bonds are long-term debt securities long and medium which can be moved or transferred. The bond contains an appointment from the issuer, to pay interest at the specified period and repay the debt principal at a certain time to the bond buyer. So, transaction bonds can have a legal effect on accounts payable. Bond issuing company called the party that has debt (debt/debtor), while the purchase of bonds called the party that has the receivables (debt/creditor). ${ }^{4}$ There is issuance bonds means the collection of funds from the fund holders. This fund can used for business expansion of the publisher or for other purposes of the publisher. Collecting funds through the issuance of bonds is not an easy matter carried out, various disclosure procedures required must first carried out by parties who want to issue bonds.

Increased growth requires a substantial investment. However, with the limitations of the Government's budget, use Government budgets need to be focused on a sector or sector that can encourage growth in the economy. ${ }^{5}$ To provide infrastructure adequate to encourage economic growth is not an easy thing, large funding is also needed for this.

Investment efficiency is needed in the use of funds needed in a large infrastructure sector. The government with efforts to find funding sources or funding

\footnotetext{
2 ibid.[5].

3 Pandji Anoraga, Pengantar Pasar Modal (Rineka Cipta 2001).[60].

4 Iswi Hari Hariyani dan R Serfianto, Buku Pintar Hukum Bisnis Pasar Modal (Visi Media 2010).[205].

5 Rencana Pembangunan Jangka Menengah Nasional 2010-2014 mengindikasikan bahwa investasi Pemerintah untuk mendukung pembangunan nasional hanya 20\% dari PDB, sisanya dilakukan oleh Swasta.
} 
is very important and needed. The search for this source of funding is not only limited to the Central Government, but also to the Regional Government. This is because the responsibility of providing infrastructure is a burden of responsibility from the Central Government and also the Regional Government together, ${ }^{6}$ for example, it relates to area coverage. Arrangements regarding this matter are contained in Government Regulation Number 38 of 2007 concerning Distribution of Central and Regional Government Affairs.

An interesting funding source to be developed related to the Regional Government is regarding the issuance of Regional Bonds to finance infrastructure development in the regions. The choice to develop Regional Bonds is based on the small development budget in the area, making services to the community neglected. ${ }^{7}$ Regional Bonds are regions offering the public to become financiers in regional infrastructure financing through public offerings. With the existence of Regional Bonds, the government can raise funds directly from the public or the community for infrastructure development, such as the construction of toll roads, airports, terminals, railroads, and others.

Regional Government according to the prevailing laws and regulations, namely Law Number 32 Year 2004 concerning Regional Government and Law Number 33 Year 2004 concerning Regional Loans, it is possible to issue Regional Bonds to finance facilities and infrastructure. The authority to issue these Municipal Bonds certainly needs to be done carefully, because the Municipal Bonds have an obligation to return funds absorbed from the community accompanied by borrowing costs in the form of interest set forth in the Municipal Bonds. For this reason, as one of the capital market instruments, regional bonds have risks like other capital market instruments, especially in terms of repayment of debt payments at maturity.

6 Menteri PPN/Kepala Bappenas, 'Pembangunan Infrastruktur dan Sinergi Pusat-Daerah', (bahan paparan pada Seminar Nasional Sosialisasi Produk Perencanaan Kementerian Perencanaan Pembangunan Nasional/Bappenas pada 2010), Bandung (accessed on 20 March 2019)

7 Irawati Hermawan, 'Obligasi Daerah Sebagai Alternatif Pembiayaan Kegiatan Infrastruktur yang Dikerjasamakan dengan Badan Usaha', (2006) Thesis, Jakarta, Fakultas Hukum Universitas Indonesia. 
The existence of Law No. 33 of 2004 which supersedes Law Number 25 of 1999 concerning Financial Balance between the Central Government and Regional Governments provides an opportunity for regional governments to raise funds (Fund Raising) in the context of regional development and development through the issuance of regional bonds such as as stipulated in Article 57 of the Law, which more specifically regulates regional bonds as a source of regional financing. ${ }^{8}$

Arrangements regarding risks in Municipal Bonds are not the same as arrangements in corporate bonds and Corporate Bonds, basically the payment of Municipal Bonds made by the Regional Government comes from funds from the utilization/ use of infrastructure built from the issuance of these bonds and reserve funds in the APBD must be allocated for repayment of payments. it is important to examine how the regulation and process of issuing municipal bonds. So the Problem Formulation is the validity of the regulation and issuance process of Municipal Bonds and the risk of issuing Municipal Bonds in Indonesia.

\section{Discussion}

Definition of Investment According to Salim HS, and Budi Sutrisno, investment law is the whole legal rule that regulates between investors and recipients of capital, business fields that are open to investment, and regulates the processes and requirements for conducting capital investment in a certain country. ${ }^{9}$

The local government affairs related to investment are regulated in Article 30 Number 2 of Law No. 25 of 2007 Concerning Investment which states that the regional government carries out investment affairs that are its authority except the affairs of managing investments which are central government affairs.

Bond is a debt contract that requires the borrower to return the loan principal back plus interest from the principal in accordance with the time determined by

8 Dewi Okta, 'Analisis Peluang Penerbitan Obligasi Daerah Sebagai Alternatif Pembiayaan Daerah’ (2011) 5 Journal of Indonesian Applied Economics.[157].

9 Salim HS dan Budi Sutrisno, Hukum Investasi Di Indonesia (PT Raja Grafindo Persada 2008).[10]. 
the party concerned. ${ }^{10}$ The Regional Government can issue regional bonds only to finance investment activities in the public sector that generate revenues and provide benefits to the community that are the affairs of the regional government. With these provisions, regional bonds issued by the government are only types of income bonds (revenue bonds). ${ }^{11}$

Bonds can be said to be one of the capital market instruments that provide fixed income securities for the holders. Bonds can be used as an alternative funding through attractive debt for companies and the government, because bonds have a relatively long and cheaper average. Due to the debts carried out directly to the community (capital suppliers).

Newly issued bonds, usually when sold, will be the same and close to their nominal value. Because the interest on bonds that will be implied has an interest rate that is almost the same as the interest rate on the market, with the level of profits provided by investors on a bond

In analyzing the Regulations and Issuance Process of Municipal Bonds in Indonesia, the author will explain one by one any regulations relating to Municipal Bonds and the author will explain the regulations relating to the issuance of Municipal Bonds, namely in Law Number 33 of 2004 concerning Financial Balance between Central Government and Regional Government, Government Regulation Number 30 of 2011 concerning Regional Loans and Minister of Finance Regulation Number 180/PMK.07/2015 concerning Amendments to Minister of Finance Regulation Number 111/PMK.07/ 2012 concerning Procedures for Issuance and Accountability of Municipal Bonds.

\section{Law Number 33 of 2004 concerning Financial Balance between the Central Government and Regional Government}

Based on Article 1 point 4 of the Minister of Finance Regulation number

\footnotetext{
${ }^{10}$ HM Jogiyanto, Teori Potokfolio Dan Anlisis Investasi (7th edn, BPFE 2010).[11]

${ }_{11}$ Kementerian Keuangan Direktorat Jenderal Perimbangan Keuangan, 'Definisi Obligasi Daerah' (Kementerian Keuangan Direktorat Jenderal Perimbangan Keuangan, 2015) <www.djpk. depkeu.go.id/?page_id=332> accessed 3 April 2019.
} 
47/ PMK.07/2011 concerning Procedures for Settling Regional Government Loan Arrears to the Government Through Sanctions for Withholding General Allocation Funds and/ or Production Sharing Funds namely Regional Government Loans, hereinafter referred to as Regional Government Loans, are all transactions that result in the Regional Government receiving a sum of money or receiving benefits that are worth money so that the Regional Government is liable to repay.

This is done when local governments need loans in handling regional infrastructure. The loan can be obtained from the community in the form of regional bonds, from the private sector in the form of cooperation, and from the government in the form of short, medium or long-term loans. Bonds, namely recognition of debt that has been issued by the government or company, with a period of at least one year. ${ }^{12}$

Regional loans are only limited to financing an activity in the form of regional investment in the context of public services where these activities generate an income for the APBD in the form of levies from the use of facilities. ${ }^{13}$ This is in accordance with what is stipulated in PP No. 30 of 2011 concerning Regional Loans, Regional Bonds must be in the form of income bonds, namely bonds that are used to fund an investment activity that generates revenue and provides several benefits to the community. However, this does not mean that it must achieve a full cost recovery. ${ }^{14}$

Payment risks in regional bonds differ from those of corporate or state bonds. Regional bonds, the payment comes from funds for the use of infrastructure for the proceeds from regional bond funds. So that the payment is gradual, depending on the time period or maturity of debt payments agreed upon between the Regional Government and the issuer. ${ }^{15}$ In general, bonds are issued for a relatively long

12 Purwosutjipto, Pengertian Pokok Hukum Dagang Indonesia (Bentuk-Bentuk Perusahaan) (Djambatan 1999).[203-208].

${ }^{13}$ Article 3(1) Regulation of the minister of finance number 180/PMK.07/2015 concerning amendment to regulation of the minister of finance number 111/PMK.07/2012 concerning of issuance and accountability of regional bonds.

14 Agni Indriani, 'Kenapa Obligasi Daerah Menarik Untuk Diterbitkan?' (Departemen Keuangan, 2013) < http://www.bppk.depkeu.go.id/webpkn/attachments/782_Kenapa Obligasi Daerah Menarik Untuk Diterbitkan - Agni - OK.pdf> accessed 3 April 2019.

15 Article 7(4) Regulation of the minister of finance number 180/PMK.07/2015 concerning amendment to regulation of the minister of finance number 111/PMK.07/2012 concerning of issuance and accountability of regional bonds. 
period of time, where the period can reach more than 5 years. With these characters, regional bonds will fall into the category of long-term loans. This is in accordance with Article 52 paragraph (4).

Article 53 paragraph 3 and 4, namely:

"Long-term loans are used to finance investment projects that generate revenue"

"Medium-term and long-term loans must obtain DPRD approval"

From article 53 paragraph 3 , it is concluded that from the funds for issuance of municipal bonds as one form of long-term loans that may only be used to finance investment projects (construction of facilities and infrastructure) that generate income. To obtain the loan, the Regional Government must obtain approval from the DPRD, including in the case of the loan being loaned to the BUMD. ${ }^{16}$ Regional bonds have several different characteristics, namely:

a. In the form of long-term loans from the community by selling shares in the capital market with a repayment period of 5 years;

b. Issued from public offering activities in the domestic capital market;

c. In Rupiah;

d. The value of the bonds is the same at the time of issuance and at maturity. Do not change;

e. The results are used to finance public fixed assets by generating benefits for the community. ${ }^{17}$

If the Local Government defaulted on local bonds or do not fulfill the obligation to pay has been set out in Article 64 that:

1) All Regional Loan obligations that are due must be budgeted in the APBD of the relevant fiscal year;

2) In the event that the region does not fulfill the obligation to repay the loan to the Government, the obligation to pay the loan shall be calculated with the DAU and/ or the Revenue Sharing Fund from the State Revenue that becomes the right of the area.

So according to the author in this matter Law Number 33 of 2004 concerning Financial Balance between the Central Government and Regional Governments

\footnotetext{
${ }^{16}$ Budi S. Purnomo, Obligasi Daerah (Alfabeta 2009).[77].

17 ibid.[1-2].
} 
stipulates that in issuing regional bonds the previous Regional Government must have obtained approval from the DPRD, and the central government, regional bonds are issued in accordance with the rupiah currency Article 54 and 55 of Law Number 33 of 2004 concerning Financial Balance between the Central Government and Regional Governments. For the issuance of Regional Bonds approved by the Regional Government, it must stipulate it in a regional regulation announced in the regional sheets. If the DPRD has approved the existence of regional bonds, the DPRD automatically approves all payments and repayments of all future financial obligations. All obligations and principal of regional bonds must be allocated in the APBD every year until the end of the obligation.

In order to account for the issued municipal bonds, the regional head appoints a work unit. In the management of the work unit designated by the head of the region must prepare a strategy and management policy for local bonds including risk control, structure of the regional loan portfolio, issuance and sale of regional bonds, making policies that allow the Regional Government to buy back the bonds before maturity. As well as preparing for repayment at maturity and taking responsibility for all activities in the management of Municipal Bonds.

Matters relating to the risk of default on municipal bonds have not been regulated in Article 64 of Law 33 of 2004 described above, the above arrangement only regulates repayment at maturity and is accountable for all activities in managing Municipal Bonds, ie if the region does not fulfill its obligation to pay loans to The government, the obligation to repay loans is calculated with DAU and/ or Profit Sharing Funds from State Revenues that are the rights of the region. So in this case if the region has obtained approval from the DPRD, the obligation to settle the bond is based on the DAU and/ or the Revenue Sharing Fund which is indeed part of the region.

\section{Government Regulation Number 30 of 2011 concerning Regional Loans}

Not much different from the regulations in Law No. 33 of 2004, regulation of the provisions concerning the definition of regional bonds in Government Regulation No. 30 of 2011, which is regulated in Article 1 number 11, namely: 
Regional taxation offered to the public through public offerings in the capital market. Whereas according to Law No. 8 of 1995 concerning Capital Market namely:18

1. An alternative in the form of securities which can be made as evidence of debt for financing originating from other sources;

2. Can be traded in the capital market;

3. Must be guaranteed by the insurer in terms of return of principal, coupons and other agreements;

4. Published by the central and regional governments and BUMN or private.

The author will explain the procedure for issuing local government bonds, regulated in Article 44 paragraph (1) Government Regulation Number 30 of 2011, namely the government submits several plans related to the issuance of regional bonds to the Minister of Finance for approval from the DPRD.

In the case of payment obligations on Municipal Bonds, this government regulation has regulated it, which is set out in Article 46, namely: ${ }^{19}$

1) Regional Governments must pay:

a. principal and interest of each Municipal Bond at maturity; and

b. penalty for late payment of principal and interest on the Municipal Bonds.

2) Payment as referred to in paragraph (1) is budgeted in the APBD every year until the end of the obligation;

3) Payment as referred to in paragraph (1) originates from regional revenues originating from the receipt of activities financed by the Municipal Bonds;

4) In the event that the activity has not generated sufficient funds to pay the principal, interest, and fine of the Municipal Bond, the obligation to pay is paid from other regional revenues;

5) In the event that the obligation to pay the Regional Bond interest that has matured exceeds the budgeted funds, the governor, regent or mayor will still make payments in the amount of the amount due;

6) The realization of the obligations of the Municipal Bond interest payment as referred to in paragraph (5) shall be budgeted for in the APBD changes and/ or included in the budget realization report.

From the above arrangement, it can be concluded that the repayment of regional bonds is to use funds in the budget in the APBD until the end of the obligation and in the event that the activity has not funded the principal, interest, and fine of the regional bonds, then the payment will be used using other regional revenues. It is different

18 2006, Obligasi Daerah Sebagai Alternatif Pembiayaan Pembangunan Daerah Di Indonesia (2nd edn, Prosiding Kopertis Wilayah IV).[4].

${ }^{19}$ Article 46 of Government regulations Number 30/2011 about regional lending. 
from the payment of interest on regional bonds, which is budgeted for changes in APBD each year and / or included in the budget realization report.

In the event of a risk of default on municipal bonds not yet regulated in this local government regulation, Article 64 is only explained, namely if the Regional Government does not fulfill the obligation to repay loans to the government, payment of obligations calculated with DAU and/ or Revenue Sharing Funds that are entitled the area. Matters concerning the settlement of DAU and / or profit sharing funds are further regulated in the Minister of Finance Regulation No. 47/PMK.07/2011.

In the opinion of the author on Government Regulation Number 30 of 2011 concerning Regional Loans not much different from Law No. 33 of 2004 concerning Financial Balance between the Central Government and Regional Governments regarding the requirements for regional loans, regional loan funding sources and loan procedures.

Minister of Finance Regulation Number 180/PMK.07/2015 concerning Amendments to the Regulation of the Minister of Finance Number 111/ PMK.07/ 2012 concerning Procedures for Issuance and Accountability of Municipal Bonds.

Regulation of the finance minister No. 180/PMK.07/2015 amended several provisions which had previously been regulated in Minister of Finance Regulation No. 111/PMK.07/2012, namely in Article 8 paragraph (2) preparation of the issuance of regional bonds namely: ${ }^{20}$

a. Determine activities;

b. Make a reference frame of activity;

c. Make a calculation of the cumulative loan limit;

d. Make a calculation of the ratio of regional financial capability to repay loans or Debt Service Coverage Ratio (DSCR); and

e. Submitting application for principle approval to the Regional People's Representative Council.

\footnotetext{
${ }^{20}$ Article 8(2) Regulation of the minister of finance number 180/PMK.07/2015 concerning amendment to regulation of the minister of finance number 111/PMK.07/2012 concerning of issuance and accountability of regional bonds.
} 
But in the Minister of Finance Regulation Number 180/PMK.07/2015 concerning Amendments to Minister of Finance Regulation Number 111/PMK.07/ 2012 concerning Procedures for Issuance and Accountability of Municipal Bonds there are additional steps in preparing organizational structures, work tools, and human resource units. Regional Bond Managers as referred to in Article 2 paragraph (7).

This means that according to the author in the context of the issuance of bonds has also arrived at the final step in terms of preparing the organizational structure and other things that participate in planned activities in the form of issuing regional bonds. In this case, more trust is created between the regional government and the existing organization in order to realize the activities that will be realized.

As well as article 9, the proposal letter must be completed by several documents, in the Minister of Finance Regulation Number 180/PMK.07/2015 concerning Amendments to the Regulation of the Minister of Finance Number 111/PMK.07/2012 concerning Procedures for Issuance and Accountability of Municipal Bonds.

According to the author, the proposal letter that must be completed is clearly regulated by Article 9, so that there is no reason for the regional government in the case of confusion to complete what letters must be prepared. This naturally facilitates the steps that must be prepared by the Regional Government.

And there are additional articles between articles 9 and 10 inserted 1 article, namely: Article 9A which reads: ${ }^{21}$

1) Minister of Finance c.q. The Director General of Fiscal Balance evaluates the administration of the planned documents for issuing Municipal Bonds as referred to in Article 9 paragraph (2);

2) Assessment. administration as referred to in paragraph (1), includes the assessment of:

a. completeness of documents on plans for issuance of Municipal Bonds;

b. suitability of documents with the format referred to in Article 9;

c. conformity of information between documents; and

d. readiness of the Regional Bond management unit.

3) In carrying out an administrative assessment of the readiness of the Regional

\footnotetext{
${ }^{21}$ Article 9A Regulation of the minister of finance number 180/PMK.07/2015 concerning amendment to regulation of the minister of finance number 111/PMK.07/2012 concerning of issuance and accountability of regional bonds.
} 
Bond management unit as referred to in paragraph (2) letter d, the Director General of Fiscal Balance shall pay attention to the considerations of the Director General of Financing and Risk Management;

4) In the event that the Bond issuance plan document is deemed not fulfilling the provisions as referred to in paragraph (2), the Minister of Finance c.q. The Director General of Fiscal Balance submits a request letter to complete and / or adjust the required documents;

5) Letter of request to complete and / or adjust the required documents as referred to in paragraph (4) shall be submitted no later than 40 (forty) working days after receipt of the letter of proposal for issuance of Municipal Bonds;

6) The Governor, regent, or mayor must complete and / or adjust the documents for the plan to issue the Municipal Bond no later than 60 (sixty) working days after receipt of the request letter as referred to in paragraph (5);

7) In the event that the Governor, regent or mayor does not fulfill the completeness and/ or adjustment of documents for the plan for issuing Municipal Bonds within the period referred to in paragraph (6), the Minister of Finance cannot further process the proposed issuance of Municipal Bonds.

Subsequent changes to the amendments to Article 10 are amended, the changes being: ${ }^{22}$

1) In the event that the plan for issuing Municipal Bonds has fulfilled the administrative assessment as referred to in Article 9A paragraph (2), the Minister of Finance c.q. The Director General of Fiscal Balance carries out a financial assessment of the documents for the plan for issuance of Municipal Bonds as referred to in Article 9.

2) Financial assessment as referred to in paragraph (1), includes the above assessment:

a. The cumulative amount of the loan, which is the amount remaining regional loans plus the number of loans will be withdrawn not exceeding $75 \%$ (seventy five percent) of the total annual revenue of the APBD previous;

b. Ratio of regional financial capacity to return a loan or Debt Service Coverage Ratio (DSCR), which is at least 2.5 (two point five); and

c. The amount of the APBD definition is in accordance with the stipulated by the Minister of Finance.

\footnotetext{
${ }^{22}$ Article 10 Regulation of the minister of finance number 180/PMK.07/2015 concerning amendment to regulation of the minister of finance number 111/PMK.07/2012 concerning of issuance and accountability of regional bonds.
} 
As well as in Article 11 there is a change in the time for the Director General of Financial Subsidies, which is initially shortened to 2 months to 30 working days after the letter of completion of the issuance of regional bonds is submitted. This will benefit the Regional Government, in terms of obtaining legal certainty. The sound of Article 11 changes to: ${ }^{23}$

1) Based on the results of the assessment referred to in Article 9A and Article 10, Director General of Financial Balance on behalf of the Minister of Finance gives approval or rejection of plans for issuance of Municipal Bonds.

2) Approval or rejection of the planned issuance of Municipal Bonds as referred to in paragraph (1) shall be issued no later than 30 (thirty) days after the plan for issuance of Municipal Bonds meets the administrative assessment.

And there is an addition to the article which is between Article 23 and Article 24 disputed 1 article namely Article 23A, namely: ${ }^{24}$

"When this Ministerial Regulation takes effect, governors, regents, or mayors who have submitted proposals for issuance of municipal bonds to the Minister of Finance in order to complete administrative documents related to organizational structures, work tools and human resources of the Municipal Bond management units as referred to in Article 9 paragraph (6)".

According to the author, the change actually benefited the Government in terms of issuing regional bonds. Especially in terms of obtaining certainty about the answers to rejecting or accepting requests for municipal bonds from the Minister of Financial Balance.

\section{Process of Issuance of Municipal Bonds in Indonesia.}

a. Publishing Procedure

In the case of the issuance of Municipal Bonds, there are several phase or steps that must be passed by the local government as an issuer. These stages in the

${ }^{23}$ Article 11 Regulation of the minister of finance number 180/PMK.07/2015 concerning amendment to regulation of the minister of finance number 111/PMK.07/2012 concerning of issuance and accountability of regional bonds.

${ }^{24}$ Article 23A Regulation of the minister of finance number 180/PMK.07/2015 concerning amendment to regulation of the minister of finance number 111/PMK.07/2012 concerning of issuance and accountability of regional bonds. 
issuance of Municipal Bonds include: ${ }^{25}$

1. Planning Phase;

2. Submission of proposals and approvals;

3. Statement of public offer registration;

4. Regional regulations concerning the issuance of Municipal Bonds;

5. Procurement of goods and services.

The stages are steps that must be taken if the issuance of Regional Bonds by the Regional Government is issued, in this case, also regulated in Government Regulation Number 30 of 2011 concerning Regional Loans if summarized in broad outline, the procedure for issuing Municipal Bonds is as follows: ${ }^{26}$

1) Planning for issuance of Municipal Bonds by the Regional Government;

2) Submission of proposals for plans for issuing Municipal Bonds from Regional Governments to the Minister of Finance c.q. Director General of Financial Balance;

3) Assessment by the Minister of Finance and Approval by the DPRD;

4) Submission of a statement on the registration of Municipal Bond public offerings to the authorities in the capital market;

5) Issuance of Municipal Bonds in the Domestic capital market.

b. Regional Bond Planning by the Regional Government

Based on the rules issued by the Minister of Finance, to achieve optimal output and outcome, it is necessary to carry outa carefulplan to issue MunicipalBonds, namely: First, the Regional Government in issuing Municipal Bonds needs to take the following steps: ${ }^{27}$

1. Determination of activities;

2. Making the terms of reference for activities;

3. Make a calculation of the cumulative loan limit;

4. Make DSCR calculations; and

5. Submitting a request for approval in principle to the DPRD.

Secondly, the head of the region requests principle approval to the DPRD which

${ }^{25}$ Regulation of the minister of finance number 180/PMK.07/2015 concerning amendment to regulation of the minister of finance number 111/PMK.07/2012 concerning of issuance and accountability of regional bonds

${ }^{26}$ Government regulations Number 30/2011 about regional lending.

27 Article 8 (2). Regulation of the minister of finance number 180/PMK.07/2015 concerning amendment to regulation of the minister of finance number 111/PMK.07/2012 concerning of issuance and accountability of regional bonds. 
includes: ${ }^{28}$

1. Maximum net value of municipal bonds to be issued;

2. Availability of payment of principal and interest due to issuance of Municipal Bonds;

3. Willingness to pay all fees arising from the issuance of Municipal Bonds.

c. Requirements for Issuance of Municipal Bonds

Based on Minister of Finance Regulation Number 180/PMK.07/2015 concerning Amendments to Minister of Finance Regulation Number 111/PMK.07/2012 concerning Procedures for Issuance and Accountability of Municipal Bonds, to be able to issue Regional Bonds the Regional Government must fulfill several requirements that must be fulfilled as the following:

1. The last audit of the financial statements of the Regional Government gets a Fair Opinion with Exceptions (WDP) or Fair Without Exception (WTP). This is in the form of a Financial Report audited by the Supreme Audit Agency. Regional Financial Reports must be prepared and presented based on government accounting standards as stipulated in PP No. 24 of 2005 concerning Government Accounting Standards. This is regulated in PP No. 23 of 2003 namely.

"Anyone who intends to utilize public funds in the capital market, either by selling shares or issuing bonds, must include financial statements including statements, which have been audited by the BPK in the event that the entity is a government organization".

2. The cumulative amount of the loan, which is the amount of the remaining regional loans + the number of loans to be withdrawn does not exceed $75 \%$ of the total general revenue of the previous year's APBD.

This means that the prerequisites and limitations that must be fulfilled by the Region in obtaining a loan, which is meant by the general revenue of the previous year's APBD, are all APBD revenues excluding Special Allocation

\footnotetext{
${ }^{28}$ Article 8 (3) Regulation of the minister of finance number 180/PMK.07/2015 concerning amendment to regulation of the minister of finance number 111/PMK.07/2012 concerning of issuance and accountability of regional bonds.
} 
Funds, Emergency Funds, old loan funds and other revenues which are restricted to finance the expenditure..$^{29}$

3. Meet the ratio of regional financial capacity to repay loans (DSCR), which is at least 2.5 (two point five).

4. Regional ability ratio is a Debt service ratio (DSCR) which is a comparison of the amount of Regional Original Revenue, Revenue Sharing Funds, and General Allocation Funds after deducting Mandatory Expenditures divided by the sum of installments of principal, interest, and other fees due. Whereas what is meant by compulsory expenditure is employee expenditure and expenditure of DPRD members. The amount of DSCR is stipulated in Government Regulations.

5. Amount of APBD deficit in accordance with stipulated by the Minister of Finance;

6. Get the approval of the DPRD which includes the maximum net value of the Municipal Bonds, the availability of principal and interest payments, and the availability of payments for all costs arising from the issuance of Municipal Bonds.

This was conveyed to the Minister for approval from the DPRD, this is what most regions usually have problems with, the approval of the DPRD is quite difficult to achieve with the current state of the region, even Jakarta which wants to issue Municipal Bonds is constrained in this process.

\section{d. Issuance of Municipal Bonds through Public Offering}

Based on Law Number 8 of 1995 concerning Capital Market, Capital Market is an activity concerned with public offering and securities trading, public companies related to securities issued, as well as institutions and professions related to securities. In connection with capital market instruments in general, bonds are one of the capital market instruments which are debt securities. A bond is a certificate that contains a contract between an investor / bond holder and a party

${ }^{29}$ Op.,Cit, Budi S. Purnomo, [78] 
that issues bonds, stating that the investor / bond holder has lent a certain amount of money to the issuing party. The party that issues the bond has the obligation to pay interest on a regular basis in accordance with the predetermined time period and the loan principal at maturity. In relation to the Municipal Bonds, the party that issues Regional Bonds is the Regional Government and the Municipal Bonds are used to finance projects that can provide benefits to the public and generate revenue. Municipal Bonds are due for more than one year. ${ }^{30}$

In general, the issuance of Regional Bonds must go through three stages, namely the pre-registration stage, the registration phase and the bidding and recording stages. ${ }^{31}$ The pre-registration stage includes the steps that must be taken before submitting a registration statement to the authority in the capital market sector which includes including appointing supporting professions, conducting due diligence, securities rating, preparation of registration statements, making related agreements (with stock exchanges, KSEI, trustee) and determination of the structure of Municipal Bonds. The stage before registration can only begin after the Minister of Finance gives approval on the proposal for the issuance of Municipal Bonds. If the pre-registration stage has begun, and the Minister of Finance does not give approval, all costs incurred in conducting the pre-registration stage will expire. After the stage before registration, the issuance process of the Municipal Bonds enters the registration stage. The registration phase lasts 45 days after the registration statement is submitted to the Authority in the capital market. During the registration phase, review of disclosure by the Authority in the capital market is carried out and an assessment of listing requirements by BES. If the requirements for disclosure are complete, the Chairperson of the Capital Market Authority will issue an effective statement in the framework of the public offering. After the registration statement for the Municipal Bond is declared effective by the capital

\footnotetext{
${ }^{30}$ Law Number 8 of 1995 concerning capital market.

${ }^{31}$ Kementerian Keuangan, 'Pasang Surut (Rencana) Penerbitan Obligasi Daerah' (Kementerian Keuangan, 2015) <https:/www.kemenkeu.go.id/publikasi/artikel-dan-opini/pasang-surut-rencana-penerbitan-obligasi-daerah/> accessed 2 April 2019.
} 
market authorities, the issuance process of Municipal Bonds enters the stage of public offering and listing in the capital market. ${ }^{32}$

At the public offering stage in the capital market, securities sales are traded on the primary market and the secondary market. The primary market is a market where securities are traded for the first time, before they are listed on the stock exchange. Municipal Bonds were offered for the first time to investors by securities underwriters (underwriters) or securities brokers who acted as sales agents for Municipal Bonds. The Secondary Market is a market where the Municipal Bonds listed in the Stock Exchange are sold. The Secondary Market provides an opportunity for investors to buy or sell Municipal Bonds listed on the stock exchange, after the implementation of the initial public offering.

Based on the rules above, the author has explained related to the regulation and issuance process of Municipal Bonds contained in Law No. 33 of 2004 concerning Financial Balance Between Central Government and Regional Government, Government Regulation Number 30 of 2011 concerning Regional Loans and Ministerial Regulations Finance Number 180/PMK.07/2015 concerning Amendments to the Regulation of the Minister of Finance Number 111/ PMK.07/2012 concerning Procedures for Issuance and Accountability of Municipal Bonds, already in sufficient steps, namely in terms of preparing organizational structures and other matters that participate in activities planned in the form of issuing regional bonds. In this case, more trust is created between the regional government and the existing organization in order to realize the activities that will be realized. However, speaking of default, the regulations above according to the author have not provided a regulation on how the Regional Government defaults on the payment of Municipal Bonds, the above arrangement only regulates how the government repays Municipal Bond principal debt, interest from Municipal Bonds and the Municipal Bond fine. 


\section{Conclusion}

From the discussion that has been described by the author above, it can be concluded as follows:

a. That all rules relating to the procedures and issuance of municipal bonds are clear and regulated in law, namely Law Number 33 of 2004 concerning Financial Balance between the Central Government and Regional Government, Government Regulation Number 30 of 2011 concerning Regional Loans, Minister of Finance Regulation Number 180 / PMK.07 / 2015 concerning Amendments to the Regulation of the Minister of Finance Number 111 / PMK.07 / 2012 concerning Procedures for Issuance and Accountability of Municipal Bonds. Issuance of bonds can also be done through a public offering.

b. Procedure for Issuance of Regional Bonds has also been contained in Government Regulation Number 30 of 2011 concerning Regional Loans.

Stages in the issuance of Municipal Bonds include:

1. Planning Phase

2. Submission of proposals and approvals

3. Statement of public offer registration

4. Regional regulations concerning the issuance of Municipal Bonds

5. Procurement of goods and services.

c. There needs to be clear guidelines and arrangements regarding the risk of default on the Municipal Bonds as well as revisions to the rules which will later replace the previous rules which are still regulated through the BAPEPAMLK Chairman's Regulation into the OJK Regulation (POJK). Because, some old rules have not accommodated developments such as for example financial statements with accounting standards that are still not updated because they are still referring to government accounting standards.

\section{Bibliography}

\section{Books}

2006, Obligasi Daerah Sebagai Alternatif Pembiayaan Pembangunan Daerah Di Indonesia (2nd edn, Prosiding Kopertis Wilayah IV). 
Agni Indriani, 'Kenapa Obligasi Daerah Menarik Untuk Diterbitkan?' (Departemen Keuangan, 2013) <http://www.bppk.depkeu.go.id/webpkn/attachments/782 Kenapa Obligasi Daerah Menarik Untuk Diterbitkan - Agni - OK.pdf $>$ accessed 3 April 2019.

Anoraga P, Pengantar Pasar Modal (Rineka Cipta 2001).

Budi S. Purnomo, Obligasi Daerah (Alfabeta 2009).

Dewi Okta, 'Analisis Peluang Penerbitan Obligasi Daerah Sebagai Alternatif Pembiayaan Daerah' (2011) 5 Journal of Indonesian Applied Economics.

Jogiyanto HM, Teori Potofolio Dan Anlisis Investasi (7th edn, BPFE 2010).

Johnny Ibrahim, Teori \& Metodologi Penelitian Hukum Normatif (Bayu Media 2013).

Kementerian Keuangan, 'Pasang Surut (Rencana) Penerbitan Obligasi Daerah' (Kementerian Keuangan, 2015) <https://www.kemenkeu.go.id/publikasi/ artikel-dan-opini/pasang-surut-rencana-penerbitan-obligasi-daerah/> accessed 2 April 2019.

Kementerian Keuangan Direktorat Jenderal Perimbangan Keuangan, 'Definisi Obligasi Daerah' (Kementerian Keuangan Direktorat Jenderal Perimbangan Keuangan, 2015) <www.djpk.depkeu.go.id/?page_id=332> accessed 3 April 2019.

Muhammad A kadir, Hukum Dagang Tentang Surat-Surat Berharga (Citra Aditya Bakti 1998).

Peter Mahmud Marzuki, Penelitian Hukum (Kencana Prenadamedia Group 2005). —

Purwosutjipto, Pengertian Pokok Hukum Dagang Indonesia (Bentuk-Bentuk Perusahaan) (Djambatan 1999).

Riduwan, Metode Dan Teknis Menyusun Tesis (Alifabeta 2009).

Salim HS dan Budi Sutrisno, Hukum Investasi Di Indonesia (PT Raja Grafindo Persada 2008).

Serfianto IHH dan R, Buku Pintar Hukum Bisnis Pasar Modal (Visi Media 2010). Soerjono Soekanto, Penelitian Hukum Normatif Suatu Tinjauan Singkat (Raja Grafindo Persada 2011). 


\section{Regulations}

Law Number 8 of 1995 concerning capital market.

(Indonesia State Gazzete Year 1995 Number 64, Additional of Indonesian State Gazzate Number 3608).

Government regulations Number 30/2011 about regional lending.

Regulation of the minister of finance number 180/PMK.07/2015 concerning amendment to regulation of the minister of finance number 111/PMK.07/2012 concerning of issuance and accountability of regional bonds.

HOW TO CITE: Sarah Wina Annisa, Mega Rahmawati Combo and Azizah Afaf, 'Prosperity of the Process and Issuance of Regional Bonds and Risk of Public Bonds Registration in Indonesia' (2019) Vol. 2 No. 1 Notaire. 